\title{
EVALUASI REPRODUKSI TIGA POPULASI IKAN PATIN SIAM Pangasionodon hypophthalmus PADA GENERASI KEDUA
}

\author{
Sularto*), Wartono Hadie ${ }^{* *}$, dan Rani Hafsaridewi ${ }^{* * *}$ \\ *) Balai Penelitian Pemuliaan Ikan \\ Jl. Raya Sukamandi No. 2, Subang, Jawa Barat 42516 \\ E-mail: sularto61@xl.blackberry.com \\ *) Pusat Penelitian dan Pengembangan Perikanan Budidaya \\ JI. Ragunan 20, Pasar Minggu, Jakarta Selatan 12540 \\ ${ }^{* * *)}$ Balai Besar Sosial Ekonomi Kelautan dan Perikanan \\ JI. K.S. Tubun, Petamburan VI, Slipi, Jakarta
}

(Naskah diterima: 13 Januari 2011; Disetujui publikasi: 29 Februari 2012)

\begin{abstract}
ABSTRAK
Penelitian dilakukan untuk mengetahui keragaan trait reproduksi ikan patin siam generasi F-1. Ikan uji yang digunakan adalah tiga populasi patin siam hasil seleksi pada tahun 2004. Ikan dipelihara dalam jaring yang ditempatkan dalam kolam $6.000 \mathrm{~m}^{2}$ dengan kedalaman antara 1,25-1,5 m. Pakan berupa pelet komersial dengan kadar protein $28 \%$ diberikan sebanyak $2 \%$ bobot biomassa/ hari. Parameter yang diamati adalah perkembangan gonad, fekunditas, fertilitas, dan daya tetas. Parameter pendukung adalah kualitas air dan tingkat curah hujan. Pengamatan perkembangan gonad dilakukan setiap bulan. Hasil penelitian menunjukkan bahwa ikan patin populasi Sukamandi mempunyai fekunditas tertinggi yaitu $201.319 \mathrm{butir} / \mathrm{kg}$ induk diikuti oleh populasi Jakarta 163.348 butir dan populasi Sukabumi 132.340 butir. Nilai indeks ovosomatik tertinggi terdapat pada populasi Sukamandi sebesar $16,52 \%$ diikuti populasi Jakarta $14,63 \%$ dan populasi Sukabumi $10,79 \%$ Diameter oosit terbesar terdapat pada populasi Jakarta yaitu $1,08 \mathrm{~mm}$; demikian pula panjang larva tertinggi pada populasi Jakarta yaitu $3,79 \mathrm{~mm}$. Derajat fertilitas tertinggi terdapat pada populasi Sukamandi yaitu $67,88 \%$ sedangkan derajat penetasan tertinggi terdapat pada populasi Sukabumi yaitu $96,67 \%$
\end{abstract}

KATA KUNCl: trait reproduksi, Pangasionodon hypophthalmus, fekunditas, daya tetas

ABSTRACT: The evaluation of reproduction trait of three difference population of Pangasionodon hypophthalmus $2^{\text {nd }}$ generation. By: Sularto, Wartono Hadie, and Rani Hafsaridewi

Research have been conducted to evaluate fish reproduction trait of patin siam $2^{\text {nd }}$ generation. Fish used are three populations patin siam result of selection in the year of 2004 . Fishs reared in the cage placed in pond $6,000 \mathrm{~m}^{2}$ with depth between 1.25 and $1.5 \mathrm{~m}$. Feed used of commercial palette with protein $28 \%$ given by $2 \%$ of biomas weight/day. Parameter observed is development of gonad, fecundity, fertility, and hatching rate. Supporter parameter is water quality and dry or wet season. Observation of development of gonad there performed every month. Result of the research indicates that fish population of Sukamandi has highest fecundity that is 201,319 eggs/ kg; followed by population of Jakarta 163,348 eggs/ kg; and population of Sukabumi 132,340 eggs/ $\mathrm{kg}$ body weight. Highest ovosomatic index value at there 
is at population Sukamandi equal to $16.52 \%$, followed by population Jakarta $14.63 \%$ and population Sukabumi $10.79 \%$ The biggest oocyte diameter there is at population Jakarta that is $1.08 \mathrm{~mm}$, and so do length of highest larva at population Jakarta that is $3.79 \mathrm{~mm}$. Degree of highest fertilisation rate there is at population Sukamandi that is $67.88 \%$, while highest hatching rate there is at population of Sukabumi $96.67 \%$

KEYWORDS: reproduction trait, fecundity, ovosomatic index, Pangasionodon hypophthalmus

\section{PENDAHULUAN}

Teknologi reproduksi pada ikan patin terutama pada patin siam, patin jambal, dan patin nasutus telah berhasil dikuasai oleh para pembudidaya. Ikan patin dengan karakter fekunditas yang tinggi memberi peluang penggunaan induk dalam jumlah sedikit. Penggunaan induk yang terbatas serta manajemen pengelolaan induk (broodstock management) yang tidak baik akan menjadi penyebab terjadinya penurunan mutu genetik. Dewasa ini mulai dikeluhkan oleh beberapa pembudidaya adanya indikasi lambatnya pertumbuhan yang disertai peningkatan konversi pakan yang berakibat menurunnya tingkat efisiensi. Hal ini menuntut perbaikan mutu genetik dengan mempersiapkan calon induk unggul, meskipun lambatnya pertumbuhan dapat disebabkan oleh faktor lain seperti mutu dan manajemen pakan, serta kondisi lingkungan wadah pemeliharaan.

Penelitian mengenai perbaikan mutu genetik ikan patin, Pangasionodon hypophthalmus telah dimulai pada tahun 2004 dengan mengoleksi induk dari 3 sentra pembenihan yaitu Jakarta, Sukamandi, dan Sukabumi. Untuk mendapatkan induk unggul dilakukan melalui program seleksi dengan memanfaatkan keunggulan ketiga populasi tersebut. Pada tahun 2006 telah dilakukan seleksi calon induk berdasarkan karakter pertumbuhannya. Proses seleksi ini merupakan salah satu tahapan untuk meningkatkan mutu genetik patin. Melalui proses seleksi diperoleh induk patin yang secara fenotip unggul. Diharapkan dengan performan fenotip yang baik akan mempunyai mutu gen yang baik juga sehingga dapat menghasilkan anakan yang mempunyai fenotip yang baik dan unggul. Untuk mempertahankan mutu genetis menurut Sudarto et al. (2001), berbagai strategi dapat dilakukan, dengan memperhatikan asal- usul calon induk. Untuk mempertahankan mutu genetik dari benih yang akan dihasilkan, maka perlu pengelolaan induk yang baik melalui serangkaian kegiatan selective breeding program.

Penelitian ini bertujuan untuk mengetahui keragaan reproduksi ikan patin siam dari tiga lokasi yang berbeda, dari Jakarta, Sukamandi, dan Sukabumi.

\section{BAHAN DAN METODE}

Hewan uji yang digunakan pada penelitian ini adalah induk patin siam generasi $\mathrm{F}$ - 1 , yang terdiri atas 3 tiga populasi, yaitu Sukabumi (SKB), Sukamandi (SKM), dan Jakarta (JKT). Jumlah induk yang digunakan adalah: 15 ekor induk betina dan 12 ekor induk jantan masingmasing populasi. Semua induk betina yang digunakan berukuran 3,0-4,5 kg dan induk jantan berukuran 2- $3 \mathrm{~kg}$. Induk- induk tersebut diberi tanda (tag) yang dapat dibaca dengan menggunakan micro chip. Setiap induk dipijahkan 2 kali pemijahan, sekali pada musim hujan dan sekali pada musim kemarau. Pemeliharaan induk dilakukan di kolam percobaan Balai Penelitian Pemuliaan Ikan (BPPI) Sukamandi. Wadah pemeliharaan adalah jaring berukuran $3 \mathrm{~m} \times 3 \mathrm{~m} \times 1,5 \mathrm{~m}$ yang ditempatkan dalam kolam berukuran $6.000 \mathrm{~m}^{2}$ dengan kedalaman air 1,25-1,50 m. Untuk mempertahankan kondisi oksigen di atas 3 $\mathrm{mg} / \mathrm{L}$, maka digunakan aerasi terutama pada malam hari. Pakan yang diberikan berupa pelet komersial dengan kadar protein $28 \%$ sebanyak $2 \%$ bobot badan per hari.

Pengamatan perkembangan gonad dilakukan setiap bulan baik secara visual (morfologis) maupun pengamatan stripping untuk induk jantan dan secara kanulasi untuk induk betina. Selain itu, pengamatan secara visual pada induk jantan juga dilakukan dengan melihat genital papila baik bentuk maupun warna. Pengamatan sperma yang diperoleh dari stripping meliputi pemberian skor/ kriteria (+) untuk sperma sedikit sekali, $(++)$ untuk sperma agak banyak tetapi encer, dan $(+++)$ untuk sperma banyak dan kental. Sperma dengan 
kriteria $(+++)$ yang dapat dipakai untuk pemijahan. Pengamatan sel telur (oosit) hasil kanulasi dilakukan di bawah mikroskop dengan perbesaran 25 kali yang dilengkapi dengan mikrometer, telur yang diamati untuk keperluan ini 850 butir. Data diameter oosit dicatat sehingga menghasilnya distribusi frekuensi. Dari distribusi frekuensi tersebut akan terlihat diameter oosit dengan frekuensi tertinggi (modus) yang dapat dijadikan dasar kematangan gonad. Diameter sel telur (oosit) dengan modus $81,0 \mathrm{~mm}$ dikategorikan telah siap untuk dilakukan pemijahan. Pemijahan dilakukan dengan rangsangan ovulasi menggunakan hormon HCG dan LHRH (Ovaprim). Parameter yang diamati adalah: perkembangan gonad, diameter telur, fekunditas, fertilitas, daya tetas, ukuran larva, dan sintasan larva.

Perkembangan gonad dilihat berdasarkan diameter sel telur, yaitu dengan melakukan kanulasi kemudian dilihat distribusi diameter sel telur dengan menggunakan mikroskop yang dilengkapi dengan mikrometer. Daya tetas telur dihitung dengan mengambil sampel telur yang telah dibuahi sebanyak 100 mg (125 butir) dan ditetaskan pada wadah dengan volume $200 \mathrm{~mL}$ menggunakan air minum komersial. Media penetasan tersebut diganti airnya setiap enam jam untuk menjaga kualitas air tetap baik. Telur- telur yang tidak terbuahi pada wadah penetasan dibuang agar tidak terjadi pembusukan. Daya tetas telur dihitung dengan rumus: jumlah telur yang menetas dibagi dengan jumlah telur terbuahi dikali $100 \%$

\section{HASIL DAN BAHASAN}

Hasil pengukuran diameter oosit yang dilakukan pada induk yang berasal dari Jakarta, Sukamandi, dan Sukabumi dapat dilihat pada Gambar 1.

Dari Gambar 1 dapat terlihat bahwa pada bulan Agustus- September diameter oosit maksimum yang dapat dicapai berkisar 0,91 0,93 mm untuk populasi Sukamandi dan Sukabumi sedangkan untuk populasi Jakarta lebih besar dengan kisaran antara 0,95 dan $0,99 \mathrm{~mm}$. Pada bulan Oktober diameter oosit dapat mencapai 1,04- 1,08 mm (ukuran median). Nilai tersebut tidak mutlak dapat dijadikan acuan jika distribusi frekuensi diameter telur mempunyai jarak yang lebar, karena telur yang masih kecil tidak akan terovulasikan. Seperti diungkapkan oleh Slembrouck et al. (2005) yang melakukan pengamatan pada ikan patin jambal bahwa oosit dengan diameter di bawah modus diameternya tidak dapat terovulasikan. Sehingga untuk menentukan kematangan gonad menggunakan nilai tengah modus yaitu nilai tengah pada daerah frekuensi tertinggi.

Ukuran oosit yang siap diovulasikan pada ikan patin adalah antara 0,9 $\mathrm{mm}$ dan 1,2 $\mathrm{mm}$. Berdasarkan ukuran tersebut, maka dapat dikatakan bahwa indukikan patin dapat matang gonad pada musim kemarau (SeptemberOktober) maupun pada musim hujan (Desember). Hal ini menunjukkan bahwa ikan patin dapat memijah tidak tergantung musim.

Namun demikian jika dilihat dari distribusi ukuran oosit yang diperoleh dari setiap lokasi dan dari setiap bulannya terlihat ada keragaman. Pada musim kemarau, ukuran oosit terdistribusi pada ukuran antara 0,48 $\mathrm{mm}$ dan $1,12 \mathrm{~mm}$ dengan modus ukuran oosit $0,96 \mathrm{~mm}$. Pada musim hujan (Desember) distribusi ukuran oosit lebih besar, terdistribusi normal dengan modus $1,12 \mathrm{~mm}$. Dibanding dengan ukuran oosit pada musim kemarau, sebaran ukuran pada musim hujan lebih besar dan mayoritas oosit siap diovulasikan.

Keragaman ukuran oosit antar asal induk memperlihatkan adanya perbedaan. Pada musim kemarau (Agustus), induk asal Sukabumi memperlihatkan keragaman ukuran oosit yang lebih besar dibanding dengan induk asal Jakarta dan Sukamandi. Namun pada musim hujan (Desember), induk asal Sukamandi memiliki keragaman ukuran oosit yang lebih besar dibanding induk asal Jakarta dan Sukabumi. Walaupun demikian secara keseluruhan terdapat perbedaan ukuran oosit antara musim kemarau dan musim hujan. Pada musim hujan, induk ikan patin lebih siap mijah dibanding pada musim kemarau. Hal tersebut sering membuat pernyataan yang kurang tepat, bahwa ikan patin hanya bertelur pada musim hujan dan sulit bertelur pada musim kemarau. Atau dengan kata lain waktu pemijahan ikan patin dipengaruhi oleh musim (Zairin, 2000). Pendapat tersebut tidak sepenuhnya salah, karena terlihat bahwa pada puncak musim kemarau distribusi ukuran oosit masih beragam sehingga beberapa induk tidak siap mijah pada musim kemarau. Namun demikian beberapa induk lain dapat mijah pada musim kemarau, walaupun frekuensinya sedikit tetapi secara populasi ikan patin dapat bertelur sepanjang tahun. 


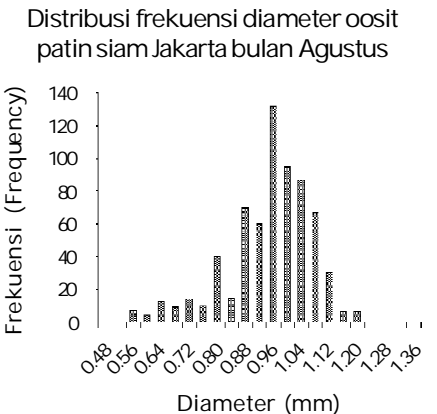

Distribusi frekuensi diameter oosit patin siam Jakarta bulan September

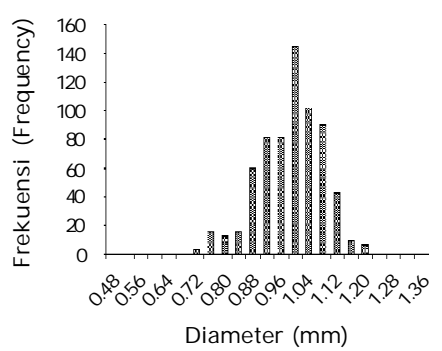

Distribusi frekuensi diameter oosit patin siam Jakarta bulan Oktober

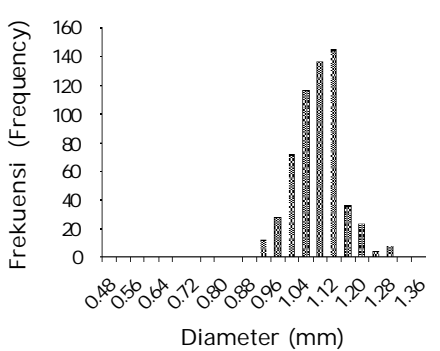

Distribusi frekuensi diameter oosit patin siam Jakarta bulan Desember

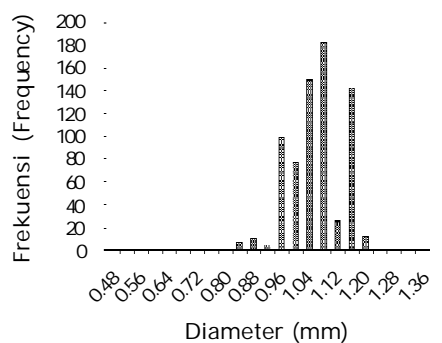

Distribusi frekuensi diameter oosit patin siam Sukamandi bulan Agustus

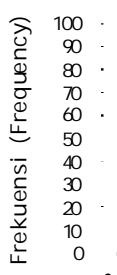

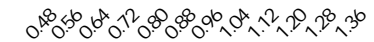

Diameter $(\mathrm{mm})$

Distribusi frekuensi diameter oosit patin siam Sukamandi bulan September

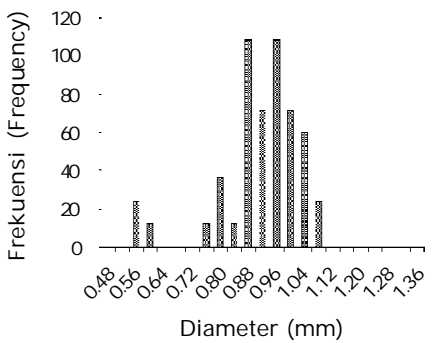

Distribusi frekuensi diameter oosit patin siam Sukamandi bulan Oktober

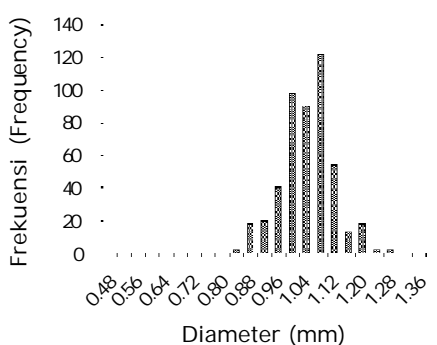

Distribusi frekuensi diameter oosit patin siam Sukamandi bulan Desember

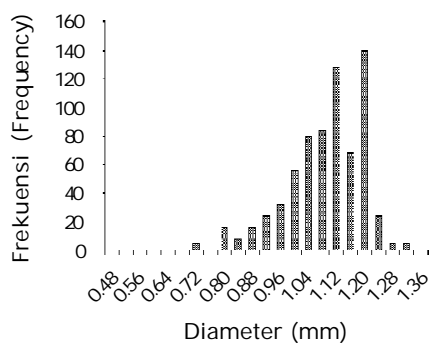

Distribusi frekuensi diameter oosit patin siam Sukabumi bulan Agustus

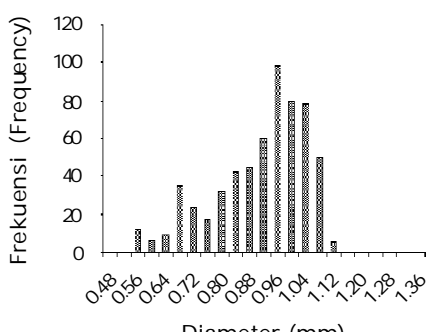

Diameter $(\mathrm{mm})$

Distribusi frekuensi diameter oosit patin siam Sukabumi bulan September

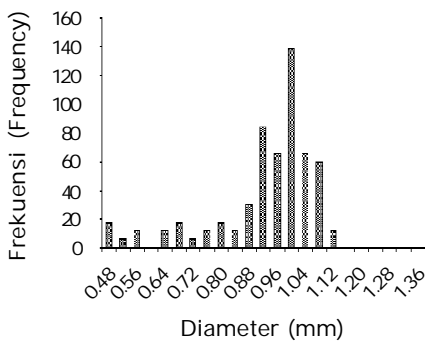

Distribusi frekuensi diameter oosit patin siam Sukabumi bulan Oktober

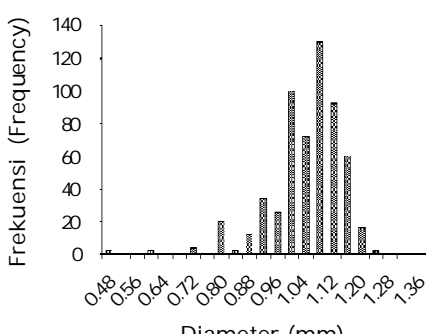

Distribusi frekuensi diameter oosit patin siam Sukabumi bulan Desember

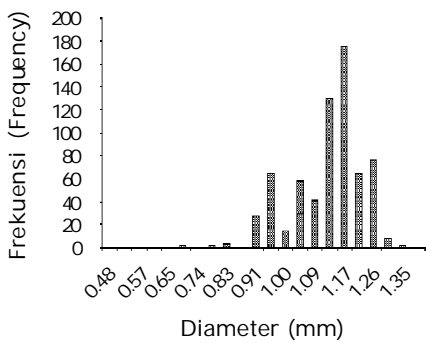

Gambar 1. Distribusi frekuensi oosit ikan patin siam populasi Jakarta, Sukamandi, dan Sukabumi pada bulan Agustus, September, Oktober, dan Desember

Figure 1. Distribution frequency of oocyt siamense catfish population from Jakarta, Sukamandi, and Sukabumi on August, September, October, and December 


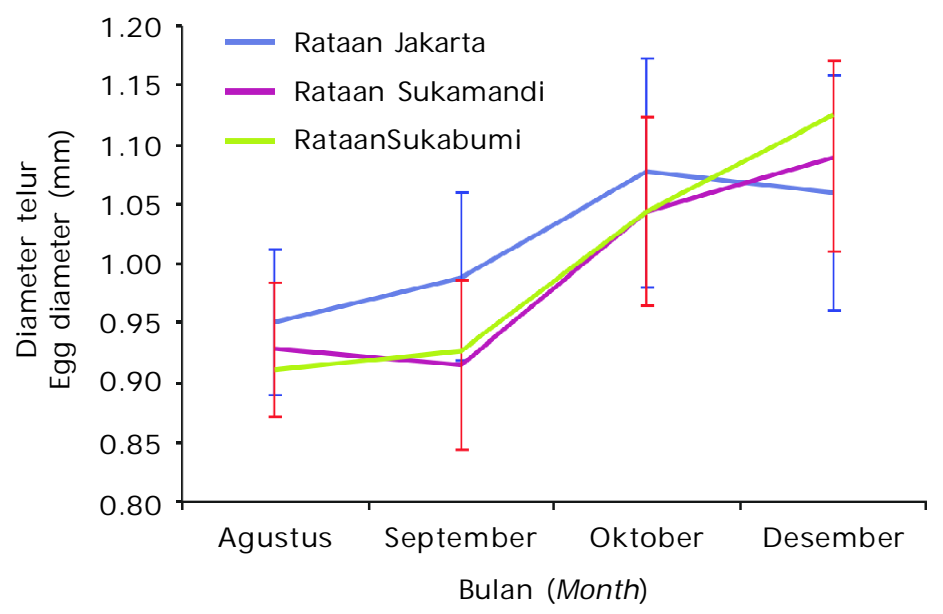

Gambar 2. Rata- rata perkembangan diameter telur ikan patin antara bulan Agustus dan Desember

Figure2. Means of egg diameter of siamese catfish developed between August and December

Penelitian keragaan reproduksi ikan patin siam generasi kedua (G-2) dari tiga populasi: Jakarta, Sukamandi, dan Sukabumi diamati berdasarkan tren perkembangan oosit dapat dilihat pada Gambar 2.

Secara umum ukuran diameter telur meningkat hingga bulan Desember, kecuali induk yang berasal dari Jakarta. Gambar 2, menunjukkan adanya perkembangan diameter telur ikan patin, yang secara umum semakin tinggi pada musim penghujan. Walaupun induk asal Jakarta terlihat menurun pada bulan
Desember, namun secara keseluruhan berdasarkan asal induk tidak memperlihatkan perbedaan yang nyata $(P>0,05)$. Hal ini menurut Hislop (1988), bahwa ukuran diameter telur juga dapat dipengaruhi oleh fekunditas, artinya semakin tinggi fekunditas diameter telur akan cenderung semakin kecil.

Hasil ini juga diperoleh dari pengamatan diameter telur, bobot telur, dan indeks ovisomatik dapat dilihat pada Tabel 1 .

Dari Tabel 1, terlihat bahwa peningkatan nilai indeks ovisomatik meningkat hingga taraf

Tabel 1. Rata- rata diameter telur, bobot telur, dan ovisomatik indeks (OSI) pada musim kemarau (Agustus- Oktober) dan musim hujan (Desember)

Table 1. Means of egg diameter, weight of egg, and ovosomatic index in the dry season (August-October) and wet season (December)

\begin{tabular}{llccc}
\hline $\begin{array}{c}\text { Asal } \\
\text { Original }\end{array}$ & \multicolumn{1}{c}{$\begin{array}{c}\text { Musim } \\
\text { Season }\end{array}$} & $\begin{array}{c}\text { Diameter telur } \\
\text { Egg diameter } \\
(\mathbf{m m})\end{array}$ & $\begin{array}{c}\text { Bobot telur } \\
\text { Egg weight } \\
\mathbf{( m g )}\end{array}$ & $\begin{array}{c}\text { Indeks ovisomatik } \\
\text { Ovosomatic index }\end{array}$ \\
\hline Jakarta & Kemarau (Dry season) & $1.006 \pm 0.018$ & $135.600 \pm 120.287$ & $5.126 \pm 4.560$ \\
& Hujan (Rainy season) & $1.059 \pm 0.099$ & $381.667 \pm 50.165$ & $14.631 \pm 0.970$ \\
\hline Sukamandi & Kemarau (Dry season) & $0.962 \pm 0.012$ & $240.200 \pm 36.421$ & $8.342 \pm 1.303$ \\
& Hujan (Rainy season) & $1.090 \pm 0.224$ & $336.300 \pm 67.444$ & $16.516 \pm 1.949$ \\
\hline Sukabumi & Kemarau (Dry season) & $0.961 \pm 0.011$ & $205.767 \pm 61.951$ & $9.020 \pm 1.929$ \\
& Hujan (Rainy season) & $1.125 \pm 0.080$ & $273.600 \pm 63.347$ & $10.787 \pm 1.741$ \\
\hline
\end{tabular}


yang signifikan pada musim hujan $(P<0,05)$, walaupun tidak berbeda nyata antar asal induk. Karena sistem pemeliharaan induk cukup seragam, terutama dalam penyediaan asupan nutrisi, maka perbedaannya dapat diduga berasal dari faktor eksternal lainnya. Rangsangan petrichor dianggap yang paling berpengaruh terhadap peningkatan OSI. Petrichor yang secara alami terjadi pada awal musim hujan merangsang insting ikan untuk melakukan reproduksi karena ada kelimpahan air dan pakan alami yang tersedia.

Keragaan induk yang matang gonad dan siap untuk dipijahkan antara bulan Agustus hingga Desember berkisar antara 25\% 100\% (Tabel 1).

Pada Tabel 2 dapat dilihat jumlah induk yang matang baik jantan maupun betina. Induk betina yang matang gonad pada bulan Agustus- September berkisar antara 20\% 33,3\% Sedangkan pada bulan Oktober menunjukkan kenaikan cukup menyolok baik dari ukuran diameter oosit maupun jumlah induk yang matang gonad. Jumlah induk yang matang dari ketiga populasi berkisar antara 73,3\% 100\% Pada penelitian ini telah dilakukan pemijahan sebanyak 2 kali yaitu pada bulan Agustus dan Oktober. Pada pemijahan bulan Agustus ternyata tidak semua induk yang diberi rangsangan hormon mengalami ovulasi. Pada pemijahan bulan Oktober semua induk yang diberi rangsangan hormon mengalami ovulasi. Berdasarkan jumlah induk betina yang matang gonad menunjukkan bahwa ikan patin siam dalam wadah budidaya di Sukamandi dapat matang gonad kembali setelah dipijahkan dalam waktu dua bulan. Hal ini berbeda dengan hasil yang dicapai di kolam budidaya di Bogor, Jawa Barat yang hanya terjadi satu kali dalam setahun (Zairin, 2000). Seperti dikemukakan Hardjamulia et al. (1987) bahwa siklus reproduksi ikan patin termasuk ikan patin siam (Pangasius hypophthalmus) di Indonesia secara alamiah hanya terjadi sekali dalam setahun yaitu pada musim penghujan (bulan Oktober-April), sedangkan di Vietnam ikan patin siam akan memijah pada bulan MeiSeptember (Cacot, 1998). Pada kondisi alami, proses perkembangan gonad ikan dipengaruhi oleh aktivitas hormon gonadotropin yang dihasilkan oleh kelenjar hipofisa, akibat rangsangan LHRH sebagai hasil respons hipotalamus terhadap sinyal- sinyal lingkungan seperti suhu, naik turunnya permukaan air, curah hujan, dan Iainnya. Menurut Hoar \& Hunter (1983) dalam Hoar et al. (1983), di lingkungan budidaya sinyal lingkungan kecil sekali, sehingga proses perkembangan gonad dan vitelogenesis berjalan lambat dan kurang efektif, sebagai hasilnya kemungkinan tidak semua telur memperoleh vitelogenin yang cukup, dan hanya sebagian kecil saja telur yang matang. Kondisi ini juga terjadi pada ikan patin siam sehingga ikan patin siam tidak bisa memijah secara alami.

Pada Tabel 2 terlihat bahwa jumlah induk yang matang gonad tidak ada perbedaan antar populasi $(P>0,05)$, namun terdapat perbedaan

Tabel 2. Jumlah induk yang matang gonad masing- masing populasi (Jakarta, Sukamandi, dan Sukabumi)

Table 2. Number of matured gonad of broodstock each population (Jakarta, Sukamandi, and Sukabumi)

\begin{tabular}{|c|c|c|c|c|c|c|c|c|c|c|c|c|}
\hline \multirow{4}{*}{$\begin{array}{c}\text { Bulan } \\
\text { pengamatan } \\
\text { Month of } \\
\text { observation }\end{array}$} & \multicolumn{12}{|c|}{ Populasi (Population) } \\
\hline & \multicolumn{4}{|c|}{ Jakarta } & \multicolumn{4}{|c|}{ Sukamandi } & \multicolumn{4}{|c|}{ Sukabumi } \\
\hline & \multicolumn{2}{|c|}{$\begin{array}{c}\text { Jantan } \\
\text { Male }\end{array}$} & \multicolumn{2}{|c|}{$\begin{array}{l}\text { Betina } \\
\text { Female }\end{array}$} & \multicolumn{2}{|c|}{$\begin{array}{l}\text { Jantan } \\
\text { Male }\end{array}$} & \multicolumn{2}{|c|}{$\begin{array}{l}\text { Betina } \\
\text { Female }\end{array}$} & \multicolumn{2}{|c|}{$\begin{array}{c}\text { Jantan } \\
\text { Male }\end{array}$} & \multicolumn{2}{|c|}{$\begin{array}{l}\text { Betina } \\
\text { Female }\end{array}$} \\
\hline & $\begin{array}{l}\text { Ekor } \\
\text { Tail }\end{array}$ & $\%$ & $\begin{array}{l}\text { Ekor } \\
\text { Tail }\end{array}$ & $\%$ & $\begin{array}{l}\text { Ekor } \\
\text { Tail }\end{array}$ & $\%$ & $\begin{array}{l}\text { Ekor } \\
\text { Tail }\end{array}$ & $\%$ & $\begin{array}{l}\text { Ekor } \\
\text { Tail }\end{array}$ & $\%$ & $\begin{array}{l}\text { Ekor } \\
\text { Tail }\end{array}$ & $\%$ \\
\hline Agustus & 3 & 25.0 & 3 & 20.0 & 3 & 25.0 & 4 & 26.7 & 4 & 33.3 & 5 & 33.3 \\
\hline September & 4 & 33.3 & 4 & 26.7 & 3 & 25.0 & 3 & 20.0 & 3 & 25.0 & 4 & 26.7 \\
\hline Oktober & 12 & 100.0 & 11 & 73.3 & 12 & 100.0 & 12 & 80.0 & 12 & 100.0 & 12 & 80.0 \\
\hline Desember & 12 & 100.0 & 11 & 73.3 & 12 & 100.0 & 13 & 86.6 & 12 & 100.0 & 9 & 60.0 \\
\hline
\end{tabular}


yang menyolok antara bulan September dan Oktober. Berdasarkan pengamatan selama penelitian berlangsung, ternyata pada bulan Oktober telah terjadi turun hujan sebanyak 2 kali. Menurut Lam (1983) dalam Donaldson \& Hunter (1983), adanya hujan akan memberikan pengaruh yang besar terhadap kondisi perairan, yakni: meningkatkan oksigen terlarut, perubahan $\mathrm{pH}$ air, serta timbulnya petrichor yang dapat mempengaruhi hipotalamus. Petrichor akan diterima sebagai sinyal lingkungan oleh hipotalamus dan mengaktifkan sel GnRH sehingga merangsang kelenjar pituitary (hipofisis) menghasilkan gonadotropin. Hipotalamus akan menginstruksikan organ yang ada di bawah pengaruhnya (poros hipotalamus - hipofisa ovari) untuk melakukan proses perkembangan dan pematangan gonad, yang melibatkan hormon-hormon steroid. Dalam hal ini hipotalamus akan menghasilkan LHRH yang akan merangsang hipofisa untuk meng hasilkan GTH (gonadothropin hormone). Gonadotropin akan merangsang sel teka pada ovari untuk mensintesis testosteron. Testosteron yang dihasilkan akan masuk ke dalam lapisan granulosa, di mana dengan bantuan enzim aromatase akan diubah menjadi Estradiol- 17 $\beta$. Hormon ini akan dilepas ke peredaran darah dan akan masuk ke dalam hati dan akan merangsang biosintesis vitelogenin. Dari data di atas dapat ditegaskan bahwa perkembangan gonad ikan patin sangat dipengaruhi oleh musim. Hal yang sama juga terjadi pada induk jantan, pada bulan Oktober- Desember semua induk jantan matang gonad. Proses pematangan induk jantan juga dikendalikan oleh hipotalamus, namun prosesnya lebih sederhana. Hipotalamus akan mengatifkan sel GnRH sehing ga memacu kelenjar pituitari gonadotropin yang akan merangsang testis untuk menghasilkan sperma.

Pada Tabel 3 terlihat indeks ovosomatik (OSI) berbanding lurus dengan nilai fekunditas relatif. Berdasarkan kedua nilai tersebut populasi Sukamandi mempunyai nilai tertinggi terutama pada musim hujan (musim pemijahan). Sedangkan berdasarkan diameter telur dan panjang larva populasi relatif lebih kecil dibanding kedua populasi lainnya. Hislop (1988) menyatakan bahwa ada hubungan yang positif antara ukuran telur dengan sintasan larva. Sedangkan untuk derajat pembuahan (fertilitas) dan daya tetas tidak memberikan pola perbedaan yang nyata. Kedua faktor tersebut sangat dipengaruhi faktor kondisi telur pada saat dilakukan rangsangan pemijahan maupun ketepatan melakukan bantuan ovulasi dan ketepatan saat pembuahan.

Berdasarkan diameter telur dan panjang larva dari ketiga populasi ternyata terdapat perbedaan antara musim kemarau (AgustusSeptember) dengan musim penghujan (Oktober). Pada musim penghujan diameter telur dan panjang larva menunjukkan ukuran yang lebih besar. Populasi Sukabumi mempunyai ukuran larva paling panjang, diikuti dengan populasi Jakarta dan terkecil populasi Sukamandi. Dengan kata lain ukuran Iarva sangat dipengaruhi oleh kondisi induk betina (maternal effect). Tingkat sintasan larva populasi Sukabumi adalah yang tertinggi diikuti populasi Jakarta dan paling rendah populasi Sukamandi. Menurut Dunham (2000), maternal effect pada ikan sangat penting selama fase awal kehidupannya. Selanjutnya dikatakan bahwa ukuran telur yang besar dapat meningkatkan daya tetas dan sintasan larvanya. Namun induk betina yang menghasilkan telur yang berukuran besar mempunyai fekunditas yang lebih rendah dibanding induk yang menghasilkan telur berukuran kecil.

Tingginya OSI dan persentase jumlah yang induk betina yang matang gonad menunjukkan bahwa musim pemijahan telah tiba (Maclnnis \&Corkum, 2000). Dengan melihat hal tersebut, maka OSI seperti halnya GSI dapat digunakan untuk menduga musim pemijahan ikan (Arruda et al., 1993). Kualitas air (Tabel 4) memperlihatkan kualitas air selama penelitian.

Berdasarkan Tabel 4 dapat dikatakan bahwa air media pemeliharaan berada dalam kisaran yang layak untuk pemeliharaan induk ikan patin siam. Suhu air, nilai $\mathrm{pH}$, dan kandungan oksigen terlarut cukup mendukung untuk memacu perkembangan gonad ikan patin. Kandungan amoniak masih dalam kisaran yang belum membahayakan kehidupan ikan. Dari kondisi kualitas air yang diperoleh, secara umum mampu mendukung perkembangan gonad secara maksimal.

\section{KESIMPULAN}

1. Populasi Sukamandi mempunyai fekunditas tertinggi, namun mempunyai ukuran diameter telur lebih kecil, serta panjang larva lebih pendek dibanding populasi lainnya. 
J. Ris. Akuakultur Vol. 7 No. 1 Tahun 2012: 11-19

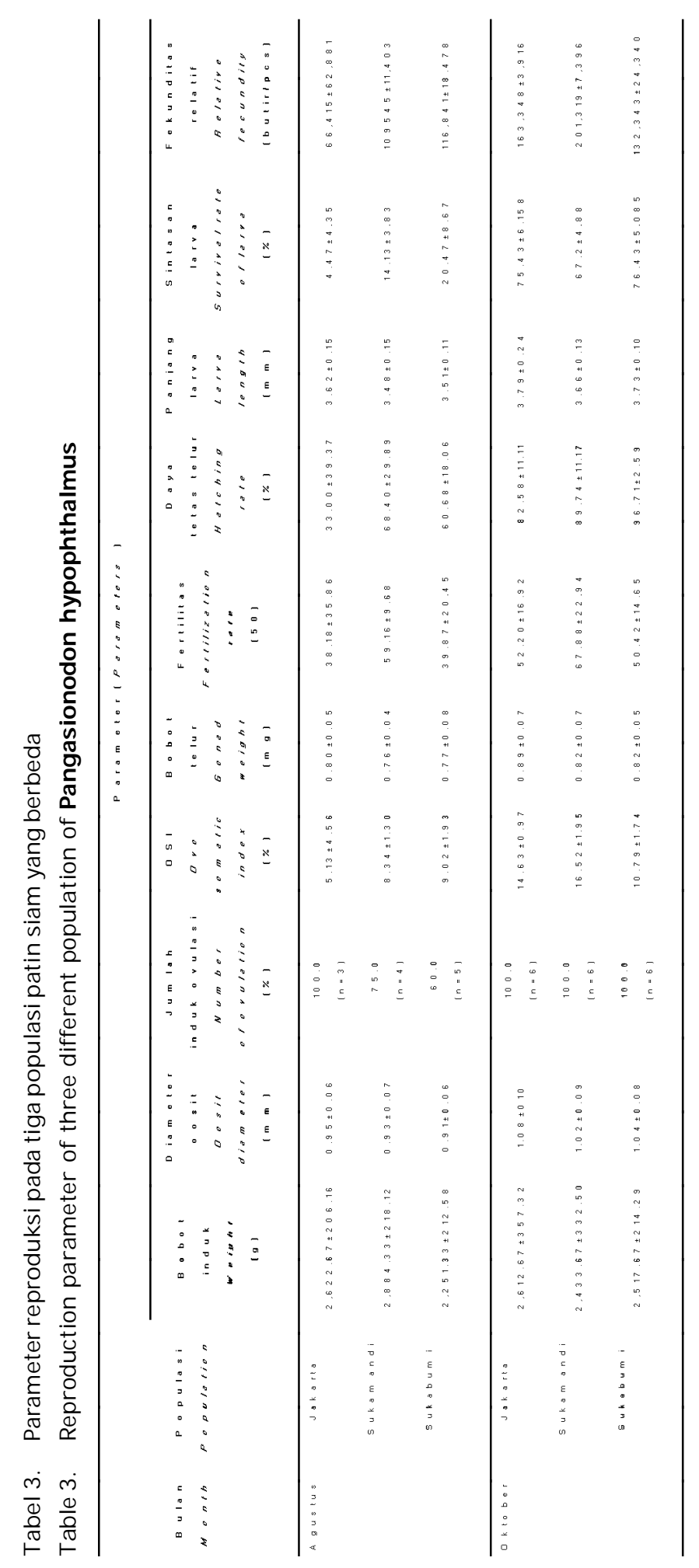


Tabel 4. Parameter kualitas air media pemeliharaan

Table4. Water quality parameter of rearing media

\begin{tabular}{lc}
\hline \multicolumn{1}{c}{$\begin{array}{c}\text { Parameter } \\
\text { Parameters }\end{array}$} & $\begin{array}{c}\text { Nilai } \\
\text { Value }\end{array}$ \\
\hline Suhu (Temperature) $\left({ }^{\circ} \mathrm{C}\right)$ & $29.00-32.50$ \\
$\mathrm{pH}$ & $7.00-8.30$ \\
$\mathrm{DO}(\mathrm{mg} / \mathrm{L})$ & $3.00-5.90$ \\
$\mathrm{NH}_{3}(\mathrm{mg} / \mathrm{L})$ & $0.75-0.21$ \\
$\mathrm{NH}_{4}(\mathrm{mg} / \mathrm{L})$ & $0.058-0.08$ \\
\hline
\end{tabular}

2. Populasi Sukabumi mempunyai ukuran larva paling besar dan sintasan larva tertinggi.

3. Ovulasi telur dipengaruhi oleh musim, pada musim kemarau 50\% 75\%populasi induk betina bisa ovulasi. Namun demikian pada musim hujan semua populasi mencapai ovulasi $100 \%$

\section{DAFTARACUAN}

Arruda, L.M., Azevedo, J.N., \& Neto, A.I. 1993. Abundance, age- structure and growth, and reproduction of gobies (Pisces: Gobiidae) in the Ria de Aviero Lagoon (Portugal). Estuar. Coastal Shelf Sci., 37: 509- 523.

Cacot, P. 1998. Description of the Sexual Cycle Related to the Environment and set up of the Artificial Propagation in Pangasius bocourti (Sauvage, 1980) and Pangasius hypophthalmus (Sauvage, 1878), Reared in Floating Cages and in Pond in the Mekong Delta. In. Legendre, M. \& Parisele, A. The Biological Diversity and Aquaculture of Clariid and Pangasiid Cathfishes in South- East Asia. Proceeding of The Mid-Term Workshop of The "Cathfish Asia Project". Cantho, Vietnam, 11- 15 Mei 1998, p. 7196.

Donaldson, E.M. \& Hunter, G.A. 1983. Induced final maturation, ovulation, and spermiation in culture fish. Fish Physiology, 9B: 351403.

Dunham, R.A. 2000. Aquaculture and Fisheries Biotechnology. Genetic Approaches. CABI Publishing.

Hardjamulia, A., Djajadiredja, R., Atmawinata, S., \& Idris, D. 1987. Pembenihan ikan Jambal Siam (Pangasius sutchi) dengan Suntikan
Ekstrak Kelenjar Hipofisa Ikan Mas (Cyprinus carpio L.). Bulletin Penelitian Perikanan Darat, 1(2): 183- 190.

Hislop, J.R.G. 1988. The Influence Maternal Length and Age on the Size and Weight of the Eggs and the Relative Fecundity of the Melanogrammus aeglefinus, in British Waters. J. Fish Biology, 32: 923- 930.

Hora, W.S., Randall, D.J., \&Donaldson, E.M. 1983. Fish Physiologi. Volume IX Reproduction Part B Behavior and Fertility Control. Academic Press. New York.

Komarudin, O. 2000. Ikan patin jambal andalan Indonesia. Warta Penelitian dan Pengembangan Pertanian, 22(3): 1- 2

Legendre, M., Slembrouck, J., \& Subagja, J. 1998. First Result on Growth and Artificial Propagation of Pangasius djambal in Indonesia. In the Biological Diversity and Aquaculture of Clariid and Pangasius Catfishes in South East Asia. Proceeding of the Midterm Workshop of the "Catfish Asia Project" Cantho, Vietnam, 11- 15 May 1998, $13 \mathrm{pp}$.

Legendre, M., Pouyaud L., Slembrouck, J., Gustiano, R., Kristanto, A.H., Subagja, J., Komarudin, O., Sudarto, \& Maskur. 2000. Pangasius djambal: A new candidate species for fish culture in Indonesia. Agency for Agricultural Research and Development. Ministry of Agriculture, Agricultural Research and Development J., 22(1): 14.

MacInnis, A.J. \& Corkum, L.D. 2000. Fecundity and reproductive season of the round goby in the upper Detroit River. Trans. Am. Fish. Soc., 129: 136- 144.

Slembrouck, J., Komarudin, O., Maskur, \& Legendre, M. 2005. Technical Manual for Artificial Propagation of The Indonesian Catfish, Pangasius djambal. IRD- PRPB. Karya Pratama, Jakarta.

Sudarto, Gustiano, R., \& Pouyaud, L. 2001. Strategi apakah yang digunakan untuk pembudidayaan Pangasius djambal secara terpadu? Program penelitian untuk pengembangan budidaya ikan patin lokal (Siluriformis, Pangasiidae) di Indonesia. Laporan ke Departemen Luar Negeri, Kedutaan Perancis di Indonesia. Unpublish.

Zairin, M.Jr. 2000. Annual Changes in Ovarian Maturity of Female Thai Catfish (Pangasius hypophthalmus) Reared in a Cultured Pond. Biotropia, 15: 48 - 57. 